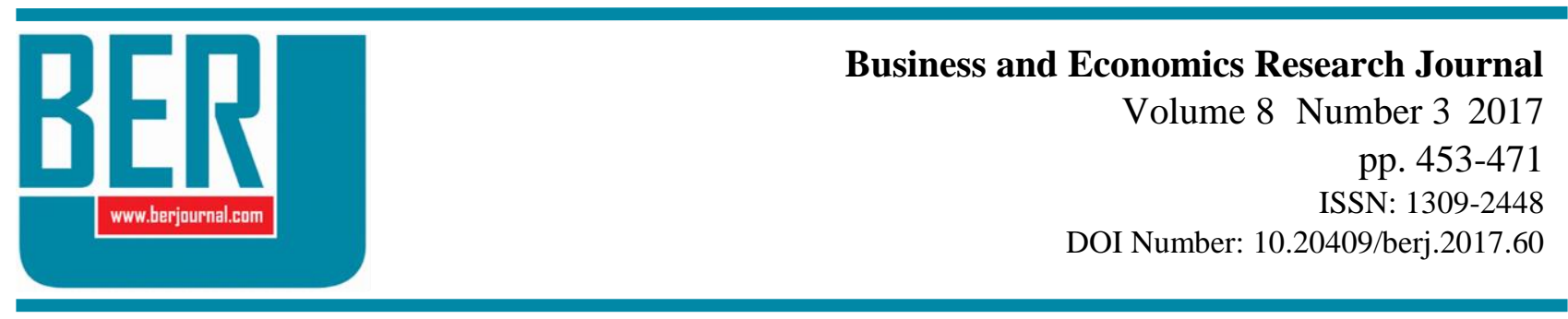

\title{
Küresel Finansal Krizin Muhasebe ve Değer Esasılı İşletme Performanslarına Etkisi
}

\author{
Ali İhsan Akgün ${ }^{\mathrm{a}}$ \\ Famil Şamiloğlu ${ }^{\mathrm{b}}$
}

\begin{abstract}
Öz: Küresel finansal kriz ile işletmenin finansal performansı arasındaki ilişkiyi analiz eden çok sayıda çalışma bulunmaktadır. Ancak, yapılan mevcut araştırmalar genellikle olumsuz bir ilişkiyi gösterse bile, bu soru hala tartışmaya neden olmaktadır. Bu konuyu alternatif bir açıdan ele almak için muhasebe temelli finansal performans ile değer esaslı ekonomik katma değer (EVA) belirsizlik dönemlerinde rol oynamaktadır mı temasını farklı bir açıdan ele aldık. Bu çalışmada, mevcut finansal krizin kriz öncesi ve sonrası referans dönemleri üzerinden BisT 100'de işlem gören şirketler için bir örnek teşkil eden finansal performans hipotezlerini test etmek amaçlanmıştir. Ayrıca bu çalışma, mevcut 2008 küresel finansal krizinin nakit oranının, likidite oranının ve nakit dönüşüm döngüsünün 2003-2012 dönemini kapsayan BiST 100 işletmelerinde bir örneğini kullanarak işletme performansı ve EVA arasındaki etkisini incelemektedir. Araştırma bulgularına göre, finansal kriz sonrası dönemde bağımsız değişkenlerin bağımlı değişkenleri açıklama gücü daha yüksek bulunmuştur. Ayrıca, kriz sonrası dönemde bağımsız değişkenlerin modern performans ölçüm göstergesi olarak kabul edilen EVA'yı açıklama gücü daha yüksek çıkmıştır.
\end{abstract}

Anahtar Sözcükler: İşletme Performansı, Finansal Kriz, EVA

JEL Sınıflandırması: G35, G32, M40, M41

\section{The Effect of Global Financial Crisis on Accounting and Value-Based Business Performances}

\begin{abstract}
There are numerous studies analyzing the relationship between global financial crisis and financial performance of business. Although, recent surveys reflect the upper hand to a generally negative relationship, this question still gives rise to debate. To approach the issue from different perspective the question that whether accounting based on financial performance and value based on Economic Value-Added (EVA) play a role during periods of uncertainty? In this study, it is purposed to test this hypothesis of financial performance acting as an sample of BiST 100 listed companies, over pre and post crisis reference periods around the current financial crisis. Furthermore, this study examines the impact of cash ratio, liqudity ratio and cash conversion cycle of the recent 2008 global financial crisis on the relation between a firm's performance and Economic Value-Added (EVA) using a sample of BiST 100 firms covering the period from 2003 to 2012. According to research findings that explanatory power of independent variables to explain dependent variables is higher in the post-financial crisis period. Moreover, EVA, which is known as a measure of modern performance in the post-crisis period, has higher explanatory power for these variables.
\end{abstract}

Keywords: Firm Performance, Financial Crisis, EVA

JEL Classification: G35, G32, M40, M41

${ }^{a}$ Assoc. Prof., PhD., Ankara Yıldırım Beyazıt University, Business School, Ankara, Turkiye, akgun@ybusm.info

bProf., PhD., Mugla Sitki Kocman University, Faculty of Economics and Administrative Sciences, Department of Business Administration, Mugla, Turkiye, familsamiloglu@gmail.com 


\section{Giriş}

2007-2009 döneminde etkili olan ABD'deki gayrimenkul ipoteğine bağlı mortgage krizi ve büyük ekonomik durgunluk, para politikasının daha etkin olarak düzenlenmesi ve uygulanması hususunda önemli bir etkiye neden olmuştur. Küresel finansal krizi takiben, Federal Reserve Kurumu, olağanüstü sayıda ek önlemler almıştır (Chen vd., 2016; 63).

Söz konusu küresel finansal krizin örneğini teşkil eden Lehman Brothers ve American International Group gibi 2008'in sonbaharında büyük finansal devlerin çöküşü, dünya finansal sisteminin kriz döneminde ne kadar kırılgan olduğunu açıkça ortaya koymuştur. G20 Maliye Bakanları, küresel finansal krizin önemli nedenlerinin finansal piyasalardaki aşırı risk alma ve hatalı risk yönetimi uygulamaları ile finansal sistem ve denetlemedeki eksiklikler olduğuna karar vermişlerdir. İleriye dönük olarak G20 tarafları, düzenleyici önlemleri güçlendirmek ve finansal sistemin doğasında olan riskleri azaltmak için çaba göstermeyi garanti altına almışlardır (Fratzscher vdl., 2016; 113-114). Dünyada olduğu gibi, Türkiye'de de finansal krizin olası olumsuz etkilerini azaltmak için bir takım ek önlemler alınmıştır. Çalışmada, küresel finansal krizin işletme performansına etkisi ampirik olarak inceleneceğinden, küresel finansal krizi azaltıcı yapısal önlemlere yer verilmeyecektir.

Literatürde finansal kriz ile işletme performansı arasındaki ilişkiyi inceleyen çalışmalarda odak noktası, işletme performansı ve hisse senedi fiyatları arasındaki ilişki (Mitton, 2002), finansal krizin banka performansına etkisi (Kwan, 2004; Peni ve Vahamaa, 2012; Kestens vd., 2012; Akhigbe vd., 2016), kurumsal sosyal performans ve işletme performansı (Ducassy, 2013; Conett et al., 2016), ve sosyal performansı ile işletme riski arasındaki ilişkiye (Bouslah vd., 2016) yoğunlaşmıştı. Ayrıca, literatürde modern ve değer temelli performans değerlemesi konusunda yapılan çalışmaların bazıları ise, EVA ile hisse senedi değeri arasındaki ilişki (Maghuga vd., 2002; Şamiloğlu, 2004a), EVA ve yönetim eylemleri arasındaki ilişki (Wallace, 1997), EVA ve firma değeri (Stewart, 1994), EVA ve hisse senedi getirisi arasında ilişki (Ismail, 2006) ve EVA ile MVA (piyasa katma değeri) arasında anlamlı ilişki olup olmadığına yönelik (Şamiloğlu, 2004b) çalışmalar bulunmaktadır. Bu çalışmada ise finansal kriz döneminde, hem geleneksel muhasebe temelli işletme performansı ve değer temelli işletme performans ölçüsü olan EVA'nın kullanımı birlikte ele alınacaktır.

2007-2009 küresel finansal krizi, hem ulusal finansal piyasalarda ve hem de uluslararası işletmelerde önemli bir etkiye sahip olmuştur. Dolayısıyla, uluslararası finansal entegrasyon süreçlerinin bir sonucu olarak, küresel finansal kriz, dünya çapındaki menkul kıymetleştirilen varlıkların değerlemesini ve işletmelerin performansını da etkilemiştir. Bu çalışma, küresel finansal kriz dönemi öncesi ve sonrasında BísT 100 endeksinde işlem gören işletmelerin performansının değerlendirilmesini hem performans ölçüleri bağlamında hem de nakit oranları bazında ele almaktadır.

Bu çalışma, önceki çalışmalardan aşağıdaki belirtilen hususlarda farklılık göstermektedir. Illk olarak, bu çalışma, 2007 küresel finansal krizine odaklanarak hem nakit oranı bileşeninin hem de işletme performansının ve EVA'nın etkisini araştırmaktadır. Söz konusu etkide 2007 finansal kriz öncesi ve sonrası karşılaştırmasına yer verilecektir. Ayrıca bu çalışmada, küresel finansal krizden kaynaklı olarak BiST 100 endeksinde işlem gören işletmelerin performanslarındaki değişikliğin incelenmesi amaçlanmıştır. Bu amaç çerçevesinde öncelikle, konunun kavramsal çerçevesi ve ilgili literatür taraması yapılmıştır. Sonrasında ise, araştırmanın hipotezlerinin gelişimi, araştırmanın örneklemi ve yöntemi ile araştırmanın bulgularına yer verilmiştir.

\section{Konuya iliş̧kin Kavramsal Çerçeve}

İşletme performansının periyodik olarak ölçülmesi, işletme içi ve işletme dışı bakış açısından olmak üzere iki sebepten dolayı yapılmaktadır. Bunlardan dış bakış açısından, yatırımcıların firmaların gelecekte kazanç potansiyeline ilişkin beklentilerini formüle etmelerinde yardımcı olmasından kaynaklanmaktadır. İ̧ bakış açısından ise, yöneticilere tahsis edilen kaynaklarını nerede kullanacakları konusunda karar vermelerine yardımcı olması, şirketin ve alt birimlerinin amaçlarını ne kadar iyi gerçekleştirdiğine yani faaliyet değerlendirmesi ilişkin makul bir geri bildirim sağlaması ve firmanın amaçlarını gerçekleştirmek için yönetim değerlendirme aracı olarak yöneticilere teşvikler veren kararların sonuçlarını ödüllendiren bir ikramiye 
planının temelini oluşturmasıdır . Ayrıca, şirketlerin kuruluş amacının esası uzun vadeli hedefi olarak hissedar değerine odaklanmaya başladığı için, kurumsal finansal performansın ölçülmesinde muhasebe temelli ölçümler açısından sadece değerlendirilmesi yetersiz görülmektedir. Dolayısıyla, muhasebe temelli ölçüler, hissedar değerini artıran faktörleri hesaba katmamaktadır. Buna bağlı olarak, değer temelli olan ekonomik katma değer (EVA), sermaye ve borcun maliyetinin hesaplanmasında, finansman riski ve getirisini dikkate alan performans hesaplamasını gündeme getirmektedir (Venanzi, 2012; ix). Böylece, bu çalışmada hem şirket içi ve hem de şirket dışı bakış açılarını birlikte ele alan muhasebe temelli performans ölçüleri ve değer temelli performans ölçülerini dikkate alan EVA ölçüsünün 2008 finansal kriz dönemi öncesi ve sonrası dönemlerindeki değişimi dikkate alınmıştır.

\subsection{Muhasebe Esaslı Performans Ölçüleri}

Geleneksel ekonomik argümanlar, yöneticilerin ekonominin her koşulunda firmaların ve sermaye sahiplerinin servetini en üst düzeye çıkaracak kararlar vermelerini önerirken, yöneticiler bunu şirketin gelecekteki nakit akışlarının bugünkü değerini en yükseğe çıkaran kararlar vererek yapması gerektiğini önermektedir. Ayrıca, iş dünyası ve bazı toplum bilimcileri ise, firmaların, sadece sermaye sahiplerinin zenginliğini maksimize etmenin ötesinde topluma karşı bir sosyal sorumluluk yükümlülüğü olduğunu savunmaktadır (Mackey vd., 2007; 817). Küresel finansal kriz dönemlerinde kurumsal yönetim özelliklerinin firmanın piyasa değerini belirlemedeki rolüne yönelik olarak ülke çapında analizler yapmış olsa da, az sayıda araştırmacı birden fazla ülkeyi derinlemesine araştırmıştır.

Mitton (2002) çalışmasında, beş Doğu Asya ülkesinin firma düzeyindeki verilerini kullanarak, Asya krizinin işletme performansı üzerinde önemli bir etkisini kurumsal yönetim uygulamaları bazında incelemiştir. Çalışmada, finansal krize karşı, şirketlerin piyasa değerinde ve işletme performanslarında önemli bir etkisi olduğu sonucuna varılmıştır. Baek vd. (2004) çalışmalarında, finansal kriz dönemlerinde yabancı yatırımcılar tarafindan daha fazla hisse sahipliğine sahip olan şirketlerin finansal krizden daha az etkilendiği ve hisse senedi değerinde daha düşük bir azalışa yol açţğına işaret etmişlerdir. Bu çalışmada, 2008 küresel finansal krizinin BIST 100'de hisse senetleri işlem gören firmaların işletme performanslarında bir etkisi olup olmadığı araştrılacaktır.

Finansal performans ölçümlerinin kullanımı, işletmelerin başarı kriterlerini değerlendirmede karşılaştğı en önemli güçlüklerden biridir. Performans ölçüm sistemleri, stratejik planların geliştirilmesinde, örgütsel hedeflerin değerlendirilmesinde ve yöneticileri ödüllendirmede önemli rol oynamaktadır (Venanzi, 2012; 9). Ayrıca, işletmelerin finansal performansı, pazar ve pazar dışı çevrelerdeki stratejilerden ve işletme faaliyetlerden etkilenmektedirler. Literatürde işletme performansına ilişkin çok çeşitli tanımlar bulunmaktadır. Bunlardan hem muhasebe ve hem de piyasa tanımını dikkate alan kurumsal sosyal sorumluluk ve firma performansı arasındaki ilişkiyi incelemek için kullanılan tanımlamadır (Orlitzky, Schmidt ve Rynes, 2003; 403-405).

Margolis ve Walsh (2001) yaptıkları çalışmalarında, işletme performansının ölçümünde muhasebe temelli ve piyasa temelli olmak üzere iki farklı finansal performans ölçümünün kullanmışlardır. Çalışmalarında, kurumsal faaliyetlerin hissedar servetini artırıp artırmadığını belirlemeye yönelik olarak, firma performansının piyasa tanımlamasını muhasebe performansı tanımlamasından daha anlamlı olduğu sonucuna varmışlardır (Margolis ve Walsh, 2001; 6-10). Bu çalışmada, hem muhasebe esaslı performans ölçümleri hem de piyasa odaklı performans ölçüm kriterleri birlikte ele alınacaktır.

Birçok firma geleneksel olarak işletme performansını ölçmek için net geliri bir performans ölçütü olarak kullanmıştır. Ancak, Rogerson (1997) çalışmasında, bu performans ölçütü yerine ekonomik katma değer (EVA)'yi kullanarak yöneticilerin daha iyi yatıı teşvikleri yaratmada önemli bir yöntem olduğunu ifade etmiştir. İşletme performansının ölçülmesinde kullanılan muhasebe esaslı performans ölçülerinin işletmenin geçmiş performansını dikkate alarak ölçülürken, piyasa bazlı performans ölçümleri gelecekteki işletme performansını ölçmektedir. Margolis ve Wals (2001) çalışmalarında da, sözü edilen performans ölçümlerinden muhasebe esaslı performans ölçümleri aktif karlılığı (ROA), öz kaynak karlıı̆̆ı (ROE) ve satış devir hızı (ROS) olmak üzere üç grupta ele almışlardır. Ayrıca, Mondal ve Ghosh (2012) ise, ROA, ROE ve ATO 
(aktif devir hızı) olmak üzere üç grupta ele almıştır. Dolayısıyla, araştırmacıların geleneksel bazlı işletme performansının hesaplanmasında kullandıkları değişkenler farklılık göstermektedir.

ROA, bir işletmenin kârlılı̆ını gösteren önemli bir oran olup, işletmenin net gelirinin toplam varlıklara oranlanmasıyla elde edilmektedir. Bu performans göstergesi, işletme yönetiminin şirket varlıklarını kullanarak gelir elde etme becerisini ölçmektedir. Başka bir ifadeyle, şirketin kaynaklarının geliri ne kadar verimli ürettiğini göstermektedir. Ayrıca, bir şirketin tüm kaynaklarından net gelir elde etmede etkinliğini de göstermektedir. Dolayısıyla, daha yüksek bir ROA, şirketin kaynaklarını kullanmada daha verimli olduğunu göstermektedir (Ongore and Kusa, 2013; 239).

ROE ise, bir şirketin net gelirinin, yatırım yapılan veya bilançoda bulunan toplam öz kaynak tutarına bölünmesiyle elde edilen finansal bir orandır. Öz kaynak kârlılı̆ı̆ yüksek bir işletmenin, nakit yaratma yeteneğinin daha yüksek olduğu söylenebilir. Dolayısıyla, ROE arttıkça, şirketin kâr yaratma açısından daha iyi olacağı düşünülür. Ayrıca bu oran, işletmenin hissedarları tarafindan yatırılan fonlarda kazanılan getiri oranını temsil etmektedir. ROE, bir işletme yönetiminin sermaye fonlarını ne kadar etkili kullanıp kullanmadığını göstermektedir. Dolayısıyla, bir işletmenin ROE'si ne kadar iyi olursa, yönetimin hissedar sermayesini kullanmada daha etkili olacağı da sonucuna varılabilir (Ongore and Kusa, 2013; 239).

\subsection{Değer Esaslı Performans Ölçüleri}

Sermayenin maliyetini performans hesaplamalarına açıkça dahil eden değer temelli performans ölçülerinin başlıcaları; ekonomik katma değer (EVA), nakit akış dönüş getirisi (CFROI), hissedar katma değeri (SVA), ekonomik değer Marjı (EM), piyasa katma değeri (MVA) ve nakit akışı katma değeri (CVA)'dir (Venanzi, 2012; 9).

Değer ve piyasa odaklı performansın temel göstergesi, Ekonomik Katma Değer (EVA)'nın finansal performansta kullanılabilir olmasıdır. Ekonomik kâr ilkesine dayanan EVA kavramının yazarları, Stern Stewart ve Co., Joel M., iki Amerikalı araştırmacıdır. EVA terimini literatürde ilk kez kullanan araştırmacı ise 1989'da Finegan, sonra Walter oldu, ancak EVA'nın işletme performansı ölçüsü olarak kullanılması 1993'te Tully tarafindan Fortune dergisinde yayınlanmasından sonra EVA finansal bilgi kullanıcılarının ilgisini çekmiştir (Berzakova vd., 2015; 319-320).

Bir şirket kendisine tahsis edilen kaynaklarla azami bir sonuç elde etmeyi hedefliyorsa, yönetim şirkette ne kadar başarılı bir değer yarattı̆ını bilmesi gerekir. Böylece, geleneksel performans ölçüm yöntemlerinin bir bilgi ekonomisi bağlamında performansı ölçmek için uygun olmadığı hususu gündeme gelmektedir. Dolayısıyla, EVA bir bilgi ekonomisi bağlamında performansları ölçmek için bir gösterge olarak kullanması önerilmektedir (Pulic, 2000; 702-705).

EVA, bir teşebbüsün gerçek ekonomik kârını hesaplamak için kullanılan finansal performans ölçüttür. Böylece, modern ekonomi ve finans alanında, EVA uygulayıcılar arasında hissedarların servetinin yaratılmasıyla doğrudan bağlantılı performans ölçüsü olduğu kabul edilebilir. Başka bir ifadeyle, EVA, kendisine emanet edilen varlıkların yönetim tarafindan hissedarlar için ne kadar fazla ekonomik değere katkı sağladığına önem vermektedir (Shil, 2009; 169).

EVA kavramı, hissedar değerinin özel çıkarları biçiminde değer yaratmak amacıyla geliştirilmiştir. EVA öncelikli olarak şirket performansının ortak bir ölçümü olarak bilinir, ancak EVA finansal analiz aracı olarak, yönetici ve çalışan teşviklerinde bir araç olarak ve şirketi değerlendirecek bir yöntem olmak üzere üç türlü kullanılabilir. EVA aracılığıyla işletme değerlemesi, işletmenin güvenilirliğini belirlemek için uygun bir araçtır ve EVA çeşitli yönetim alanları için kullanıcılara değerli bilgiler sağlamaktadır (Berzakova vd., 2015; 320).

EVA, değer yaratma ölçümü için yaygın olarak benimsenen bir tekniktir. Tortella and Brusco (2003) çalışmalarında; işletmenin kârlılık, yatırım ve nakit akış değişkenleri ile EVA öncesi ve sonrasına ilişkin gelişimini analiz etmişlerdir. Çalışmalarında, firmaların EVA'yı benimsemelerinin işletme performans göstergelerinin ancak uzun vadede iyileştiğini, yöneticilerin firmanın yatırım faaliyetlerini artırma konusunda teşvik sağladığı gibi, EVA'nın benimsenmesinin olumlu ve belirgin nakit akımlarını etkilediğini gözlemlediklerini ifade etmişlerdir. Genel olarak EVA, belirli bir süre boyunca firma tarafindan yaratlan 
ekonomik değerin, yönetici karar alma sürecinde yardımcı olan önemli değişken olarak ifade edilmiştir. Ayrıca, bir firmanın EVA'sı, bu Vergi Sonrası Net Faaliyet Karı (NOPAT) ile bu NOPAT'ı elde etmek için kullanılan Sermayenin Maliyetindeki değişimin çıkarılması ile oluşan değer olarak tanımlanmaktadır.

Dolayısıyla, geleneksel işletme performansının değerlendirilmesi yaklaşımları ile karşılaştııldığında, EVA işletmenin finansal performansının değerlendirilmesine farklı bir boyut katmıştır. Bu farklııı̆ın esas gerekçesi ise, geleneksel performans değerlendirme ölçütlerinin gerek değer yaratılması gerekse de kâr elde edilmesi noktasında işletmenin yatırılan sermayesinin maliyetini dikkate almamalarından kaynaklanmasıdır (Kyriazis and Anastassis, 2007; 72).

\section{3. İIili Literatür}

\subsection{Muhasebe Esaslı Performans Ölçülerine İlişkin Literatür}

Küresel finansal kriz ile işletme performansı konusunda birçok ulusal ve uluslararası literatürde çalışma bulunmaktadır. Ancak, küresel finansal kriz öncesi ve sonrası dönemlerde hem geleneksel işletme performansının ve hem de modern performans hesaplanmasında kullanılan EVA ile ilgili yapılan çalışmalar sınırlı ölçüde kalmıştır.

Geleneksel temelli performansı inceleyen çalışmalardan biri olan Mitton (2002) çalışmasında, finansal kriz sırasında işletme performansı ile hisse senedi fiyatları arasındaki ilişkinin yüksek olduğunu bulmuştur.

Kwan (2004) çalışmasında, varlıkların getiri ve öz kaynak kârlılığı ölçülerini kullanarak, özel ticari banka holding şirketlerinde 1984-2001 yılları arasındaki on sekiz yıllık dönemde genel finansal performansın daha iyi olduğunu ortaya koymuştur. Çalışmada, varlık yapısı daha güçlü olan bankalarda, banka performansı daha küçük varlık yapısı olan gruplara göre daha anlamlı olduğu sonucuna varmıştır. Baek vd. (2004) çalışmalarında, kurumsal yönetim uygulamalarının finansal kriz dönemlerinde firma düzeyindeki işletme performansı üzerinde önemli bir etkiye sahip olduğu kanaatine varmışlardır.

Peni and Vähämaa (2012) çalışmalarında, kurumsal yönetim uygulamalarının 2008 küresel finansal krizi sırasında banka performansı üzerindeki etkilerini incelemişlerdir. Sonuçta, daha güçlü kurumsal yönetim mekanizmalarına sahip bankaların 2008 yılında daha yüksek kârlılık ile ilişkili olduğunu ortaya koymasına rağmen, güçlü yönetişimin, kriz ortamında bankaların borsa değerlemeleri üzerinde olumsuz etkileri olduğunu gözlemlemişlerdir.

Kestens vd. (2012) çalışmalarında, 2008 finansal krizinin şirketlerin ticari kredilerini etkileyip etkilemediğini ve ticari kredisinde meydana gelen değişikliklerin finansal krizin firma kârlılı̆̆ üzerindeki etkisini azaltıp azaltmadığını araştırmışlardır. Araştırmada, finansal krizin şirket performansı üzerinde olumsuz bir etkisi olduğunu, ancak kriz öncesi dönemde kriz dönemine kıyasla finansal tablolarında ticari alacaklarda artş sunan firmalar için bu etkinin daha düşük olduğu sonucuna varılmıştr.

Ducassy (2013) çalışmasında, küresel finansal krizin başlangıcında kurumsal sosyal performans ve finansal performans arasında belirgin bir olumlu bağ olduğunu gözlemlemiş ve finansal kriz sonrasında ise bu iki değişken arasında artık önemli bir bağlantının mevcut olmadığı sonucuna varmıştır.

Akhigbe vd. (2016) çalışmalarında, 1996 ile 2006 yılları arasındaki finansal kriz öncesi dönemdeki özel ve kamuya açık ABD ticari banka holding şirketleri (BHC) ile 2007-2010 küresel finansal kriz döneminde ve sonrasında yaşanan kâr verimliliği farklılıklarını dikkate almışlardır. Çalışmalarında, özel BHC'lerin finansal kriz öncesi dönemde halka açık iş ortaklıklarından daha iyi performans gösterdiğini tespit etmişler, ancak finansal kriz dönemi olan 2007-2010 döneminde ise kâr verimliliğindeki istatistiki olarak anlamlı fark bulunamamıştır.

Hoa vd. (2016) çalışmalarında, CEO'larına aşırı güvenen bankaların borç verme standartlarını esneterek kriz öncesinde diğer bankalardan daha fazla kaldıraç sağlayarak, işletme ve hisse senedi getirisi performansında daha fazla düşüş olduğu sonucuna varmışlardır. CEO'larına aşırı güvensiz bankalar ise, diğerlerine kıyasla daha ciddi risklerle karşı karşıya kalmışlardır. Conett vd. (2016) çalışmalarında, mevcut küresel finansal kriz bağlamında bankaların kurumsal sosyal sorumluluk ile finansal performans arasındaki ilişkiyi incelemişlerdir. Çalışmalarında, aktif varlıkları büyük bankaların, örnek alınan dönem boyunca sürekli 
olarak daha yüksek kurumsal sosyal sorumluluk gücüne sahip olduklarını ve ROE'nın ise pozitif ve anlamlı ilişkili olduğu sonucuna varmışlardır.

Bhimjee vd. (2016) çalışmalarında, küresel finansal kriz öncesinde ve sonrasında bankacılık sektörünün işletme performansını analiz etmişlerdir. Çalışmada, finansal piyasalardaki durgunluk dönemlerinde kriz öncesi döneme kıyasla işletme performansının daha yüksek olduğu gözlemlenmiştir. Bouslah vd. (2016) çalışmalarında, sosyal performans ile işletme riski arasındaki ilişkinin, finansal kriz döneminde kriz öncesi döneme kıyasla önemli ölçüde farklı olduğunu tespit etmiştir. Çalışmalarına göre, piyasa koşullarına bağıı olarak sosyal performansın finansal kriz sırasında azaldığı sonucuna varmışlardır.

\subsection{Değer Esaslı EVA'ya ílişkin Literatür}

Değer temelli performans ölçümleri, bir şirketin mevcut yatırımcılarını tatmin etmek ve yeni yatırımları cazip kılmak için asgari karlılık düzeyini tanımlamaya yardımcı olmaktadır. Yönetim belirli projelerde, ürünlerde veya süreçlerde belirli yatırım firsatlarını göz önüne aldığından, maliyet bilgileri hesaplanırken toplam sermaye yükünü faaliyetler arasında bölmek mantıklı bir yaklaşım olacaktır. Bununla birlikte, bu sermaye maliyetlerinin faaliyetlere keyfi olarak tahsis edilmesi, özellikle sermaye maliyetlerinin işletme maliyetleri ile orantılı olmadığı durumlarda, maliyetlerde sapmalara neden olabilir. Bu bağlamda, ürün maliyeti bilgilerinin hesaplanmasında EVA'dan yararlanılması durumunda, yönetim daha doğru işletme karı elde edeceğinden performans göstergeleri daha anlamlı olacaktır (Roztocki ve Needy, 1999; 18-21).

Son yıllarda, birçok şirketin, EVA'yı firma performansının bir ölçüsü olarak kullanması, portföy seçim kararları için analitik bir araç olarak ve bir yönetim disiplini olarak kabul ettiği iddia edilmektedir. Akademik araştırmaların önemli bir kısmı, EVA'nın raporlanan muhasebe kazançlarından daha iyi bir değer ölçüsü olduğunun araştrılımasına odaklanmıştır. Yapılan ampirik araştırmalar ise bu iddiaya göre karışık sonuçlar vermektedir (Maghuga vd., 2002; 59-60).

Bir çok çalışma, EVA'nın hisse senedi getirileri ile büyük oranda ilişkili olduğunu iddia ederek, EVA'nın hisse senedi fiyatlarında, diğer muhasebe esaslı performans göstergelerinden daha fazla değer yarattğını ifade etmişlerdir (Stewart, 1994). Örneğin, Chen ve Dodd (1997) çalışmalarında, EVA ölçütünün geleneksel muhasebe getirileri ölçümlerinden nispeten daha fazla bilgi sağladığı ve hisse senedi getirileri ile ilişkisi bakımından yüksek korelasyon gösterdiklerini bulmuşlardır. Worthington ve West (2004) çalışmalarında ise, EVA'nın işletme net geliri ve net nakit akışlarından bilgi içeriğiyle ilgili daha anlamlı veri sağladığı sonucuna varmışlardır.

Wallace (1997) çalışmasında, geleneksel temelli bir performans ölçütünün yöneticilere hissedarlar tarafindan değer verilen kararlar vermesine neden olacağı söylenemezse de, performans ölçütleri ile yönetim eylemleri arasında bir ilişki bulunduğu sonucuna varılmıştr. Stewart (1994)'e göre EVA, finansal performansı ölçmek için kullanılan bir teknik olup, hissedarların değerinin zaman içerisinde yarattğı gerçek karı gösterdiğini ifade etmiştir. EVA yaklaşımı, firmanın firsat maliyeti ve sermaye maliyetini kapsadığı sürece firma değerini artırabileceğini vurgulamıştır.

Maghuga vd. (2002) çalışmalarında, firma performansı ölçütü olarak EVA ve hisse başına kazançlarının göreli etkinliği hakkında deneysel araştırma yapmışlardır. Araştırmanın bulgularına göre, gelecekteki işletme kazançlarını tahmin etmek için kullanılan performans ölçülerinden EVA'nın hisse başına kazancı artırdığı sonucuna varmışlardır.

Şamiloğlu (2004a) çalışmasında, BiST'de işlem gören imalat firmalarına ilişkin olarak, EVA ile artık gelir ve muhasebe karlarının karşılaştırılmasına yer vermiştir. Çalışmada, BIST'de işlem gören imalat işletmelerinin hisse basına kazançlarının \%7.9'u EVA tarafindan anlamlı şekilde açıklandığı sonucuna varmıştır. Ayrıca, Şamiloğlu (2004b) çalışmasında ise, iMKB'de hisse senetleri işlem gören 184 şirketin 1995-2002 yılları arasındaki Ekonomik Katma Değerleri (EVA) ile Piyasa Katma Değerleri (MVA) arasındaki ilişkiyi incelemiştir. Çalışmada, EVA ve MVA değerleri arasındaki anlamlı bir ilişkinin olmadığı sonucuna varmıştır.

Ismail (2006) çalışmasında, EVA'nın net gelir ve vergi sonrası net gelirin hisse senedi getirisi ile ilişkili olarak artık gelirden daha iyi performans göstermediğini belirtmiştir. Ünlü ve Saygın (2014) çalışmalarında 
ise, muhasebe temelli geleneksel performans ölçüm yöntemlerinin yetersizliğinden hareketle Arındırılmış Ekonomik Katma Değer (REVA) yöntemini kullanarak BiST turizm sektörü firmalarının 2012 yılı için hissedar değeri yaratamadıklarını ve değer yaratmak yerine mevcut sermayelerini tükettikleri sonucuna varmışlardır.

Xine vd. (2012) çalışmalarında ise, EVA metodu için değer yaratma kabiliyetinin yanı sıra, ticari ve işletme bankalarının değer yaratma becerisini geliştirir, temel rekabet yeteneğini güçlendirir ve böylece ticari bankaların sürdürülebilir kalkınmasına katkı sağladığı kanaatine varmışlardır.

Sloof and van Praag (2014) çalışmalarında, Courty ve Marschke (2008) tarafindan geliştirilen ve EVA gibi artı gelir temelli performans ölçümlerinin yaygın olarak kullanılması, yöneticilere, gerçek muhasebe kârının raporlanan kazançlara bağlı olarak manipüle etmeye teşvik edeceğini ortaya koymuşlardır. Courty ve Marschke (2008) çalışmalarında, manipüle edilmiş bir performans ölçüsüne dayanan işletme performansının firma değerini olumsuz yönde etkileyeceğine işaret etmişlerdir.

\section{Araşttrma Hipotezlerinin Gelişimi}

Menkul kıymetler borsasına para yatırmanın amacı, yatırım yapılan sermaye üzerinde bir getiri elde etmektir (Vieito vd., 2016; 1066). Ancak, finansal krizler normalde finansal piyasalardaki olumsuz etkilerle ilişkilendirilmektedir. Dolayısıyla, finansal kriz döneminde işletmelerin performanslarında olumlu ya da olumsuz bir etkinin olup olmaması önem taşımaktadır.

İşletme performans ölçümü, tüm dünyada ve finans alanında araştırmaların gelişen bir alanıdır. Uzun yıllardır şirketlerin yöneticileri ve hissedarları, bir firmanın değerini ölçmek için sermayedar kârlılığı, varlık kârlıı̆̆ı, yatııım getirisi, hisse başına kazanç vs. gibi geleneksel ölçülere dayanarak hesaplamışlardır. Bununla birlikte, Hawawini vd. (2003) çalışmalarında, EVA'nın ekonomik kazanç olarak kullanılmasını ve şirket tarafindan kullanılan istihdamın maliyetini de dahil ederek, EVA'nın kısa ve uzun vadeli performans hakkında muhasebe, ekonomi ve pazar bilgisi bilgileri sunması nedeniyle firmanın değerini ölçmek için daha anlamlı gösterge olduğunu önermiştir (Shad ve Lai, 2015; 6-7). Dolayısıyla, geleneksel kurumsal performans işletmenin sermaye maliyetini dikkate almadığı için, EVA'nın sermaye maliyetine odaklanması performansı ölçmek için en önemli teknik olarak düşünülmektedir.

EVA'nın temel esası; yöneticilere, sermaye maliyetinden daha fazla gelir getiren projeler üstlenmek için ödüllendirmesi ve böylece firmanın net bugünkü değerinin artırmasıdır. Dolayısıyla EVA, firmanın net bugünkü değerini en üst düzeye çıkarmanın güçlüğünü cari yıl performansını değerlendirmek için kullanılabilecek bir ölçüye dahil etmeyi savunmaktadır. Lovata and Costigan (2002) çalışmalarında, EVA kullanan firmaların, kurumsal sahiplik oranının daha yüksek olduğu sonucuna varmışlardır.

Lev ve Zarowin (1999) finansal bilgilerin kullanışııı̆ının son yıllarda azaldığını ve finansal bilgilerin bir firmanın işletme faaliyetlerinde meydana getirdiği büyük değişiklikleri tam olarak yansıtamayacağını savunmuşlardır. Dolayısıyla, Lehn ve Makhija (1996)'e göre EVA, işletme performansın hesaplanmasında geleneksel muhasebe önlemlerinden farklı olarak, firmaların yarattğı değeri, yatırım sermayesi üzerinde oluşturduğu getirilerden bir sermaye yükümlülüğü çıkararak ölçmeye çalışmaktadır. EVA'nın performans ölçümlerinde kullanılmalarına ek olarak, yönetici telafi planları ve kurumsal stratejilerin geliştirilmesi için gösterge olarak dikkate alınabilir (Lehn ve Makhija, 1996; 34).

Yapılan bazı araştırmalarda, örneğin, Lehn ve Makhija (1996) ve Mouritsen (1998) çalışmalarında, EVA'nın bir firmanın riskini daha iyi yansıtabilir ve muhasebe kazançlarından çok firmanın değer yaratma yeteneğini daha fazla temsil ettiğini ortaya koymuşlardır. Bununla birlikte, Chen ve Dodd (1997), EVA'nın işletme gelirinden daha fazla bilgi içeriği sağlamakla kalmadığı aynı zamanda EVA'nın muhasebe gelirinin ölçülmesinde ve firmaların değerlemesinde önemli olduğunu ortaya koymuşlardır.

Stewart (1991) çalışmasında, belirli geleneksel muhasebe karının kalemlerinin düzeltilmesinden elde edilen finansal performans ölçütlerinden biri olan EVA'nın geliri ölçmek için daha anlamlı olduğunu gözlemlemiştir. Huang and Wang (2008) çalışmalarında, firma değerinin esas olarak defter değeri, EVA ve entelektüel sermaye tarafindan belirlenmesini ampirik olarak incelemişlerdir. Özellikle, bu çalışmada, entelektüel sermayenin Menkul Kıymetler Borsası'nda işlem gören firmaların değeri ile ilgili bilgi sağlayıp 
sağlamadığını bulmak için, GAAP muhasebe kazançlarına ve EVA'ya dayanan firma piyasa değeri esas alan reel gelirini karşılaştırmışlardır. Sonuçta, EVA'ya dayanan kalıcı gelirin firma piyasa değerlerinin GAAP'a dayalı gelirden yüksek olmadığını ortaya koymuşlardır. Ayrıca, yatıımcıların firmaları doğru bir şekilde değerlendirebilmesi için finansal tablolarda sunulan hem entelektüel sermayeyi hem de finansal sermayeyi dikkate alması gerektiğini sonucuna varmışlardır.

İşletmelerin küreselleşme ile zorlu bir rekabet içinde olması ve aynı zamanda finans piyasaların uluslararası bir yapıya kavuşması ve finansal piyasalarda büyük bir genişlemeye yol açmıştı. Dolayısıyla, uluslararası rekabetin güçlüklerine ve firsatlarına daha fazla maruz kalma, daha iyi performans önlemleri alma ihtiyacını artırmıştır (Tortella and Brusco, 2003; 266). Böylece, işletme performansının ölçümünde sermaye maliyetini dikkate almayan geleneksel muhasebe performans ölçüm yöntemlerinin de yetersizliği dikkate alınarak işletme performansı aracı olarak EVA yöntemine ihtiyaç duyulmuştur. Dolayısıyla, çalışmada finansal krizde işletme performansının ele alınması önemli bir değişken olduğu düşünülmüştür.

Jacobson (1987) çalışmasında, işletme performans aracı olarak faaliyet kar marjı ile hisse senedi getirisi arasındaki ilişkiyi incelemiştir. Çalışmasında, faaliyet kar marjının hisse senedi getirisi ile olan korelasyonu ne kadar güçlü olursa, işletme performansının ölçüsü olarak faaliyet kar marjının geçerliliği de o kadar güçlü olduğu sonucuna varmıştir.

Çalışmada işletme performansı olarak geleneksel performansında hesaplanmasında net gelirin öz kaynaklara oranlanmasıyla elde edilen öz kaynak kârlıı̆ııın (ROE) (Cornet vd., 2016; 144; Mondal ve Ghosh, 2012; 518), işletmenin net karının toplam varlıkların defter değerine bölünmesiyle ölçülen aktif karlılığı (ROA), ve işletmenin net satı̧larının toplam varlıkların defter değerine bölünmesiyle hesaplanan aktif devir hızı (ATO) (Mondal ve Ghosh, 2012: 518), Faiz ve Vergi Öncesi Karın Net Satışlara oranlanması ile elde edilen (OPM) (Jacobson, 1997) olmak üzere dört değişken kullanılmıştı. Ayrıca, piyasa veya değer temelli yaklaşım olan EVA firma nakit akışına odaklandığından, şirket nakit akış değişkenlerinin gelişimini ile işletme faaliyet kar marjının analiz edilmesi gerektiğini (Tortella and Brusco, 2003; 286) düşünmekteyiz. Bu bağlamda, analizde bağımsız değişken olarak BIST 100'de faaliyet gösteren işletmelerin nakit oranı, cari oranı, likidite oranı ve nakit dönüşüm döngüsü kullanılmıştır.

Böylece, araştırmada kullanılan modeller çerçevesince araştırma hipotezlerini aşağıdaki gibi belirleyebiliriz:

H1= BiST 100'de faaliyet gösteren işletmelerin nakit oranı, cari oranı, likidite oranı, nakit dönüşüm döngüsü, küresel finansal kriz dönemlerinde finansal kriz öncesi döneme göre EVA'sı üzerinde olumlu etki yapmıştır.

H2= BiST 100'de faaliyet gösteren işletmelerin nakit oranı, cari oranı, likidite oranı, nakit dönüşüm döngüsü, küresel finansal kriz dönemlerinde finansal kriz öncesi döneme göre ROA'sı üzerinde olumlu etki yapmıştir.

H3= BiST 100'de faaliyet gösteren işletmelerin nakit oranı, cari oranı, likidite oranı, nakit dönüşüm döngüsü, küresel finansal kriz dönemlerinde finansal kriz öncesi döneme göre ROE'sı üzerinde olumlu etki yapmıştır.

H4= BiST 100'de faaliyet gösteren işletmelerin nakit oranı, cari oranı, likidite oranı, nakit dönüşüm döngüsü, küresel finansal kriz dönemlerinde finansal kriz öncesi döneme göre ATO'sı üzerinde olumlu etki yapmıştır.

H5= BiST 100'de faaliyet gösteren işletmelerin nakit oranı, cari oranı, likidite oranı, nakit dönüşüm döngüsü, küresel finansal kriz dönemlerinde finansal kriz öncesi döneme göre OPM'sı üzerinde olumlu etki yapmıştır.

\section{Araştırmanın Örneklemi ve Yöntemi}

$\mathrm{Bu}$ çalışmanın birinci amacı, BİST 100 endeksinde küresel finansal krizin geleneksel işletme performansı ile nakit oranları analizine etkisi olup olmadığının belirlenmesidir. İkinci amacı ise, 2008 finansal kriz öncesi ve sonrasındaki dönemlerde BIST 100 'de hisse senetleri işlem gören şirketlerin işletme performansının hesaplanmasında EVA'yı etkileyip etkilemediğinin ortaya konulmasıdır. Bu amaç doğrultusunda, çalışma kapsamında kap.gov.tr adresinden Borsa İstanbul 100 endeksinde faaliyet gösteren 100 firmanın, 2003-2012 yılları bilanço ve gelir tabloları verilerinden yararlanıımıştır. Söz konusu çalışmada, 2003-2012 döneminin alınmasının gerekçesi ise söz konusu dönemde finansal krizin etkisinin yoğun 
olmasından kaynaklanmaktadır. Ayrıca, çalışmada BiST 100 endeksinde faaliyet gösteren işletmeler ile sınırlandırılmıştır. Araştırmada 100 işletme ve kullanılan 10 yıllık datadan hareketle 1.000 gözlem yapılmıştır.

Çalışmada bağımlı değişken olarak ROA, ROE, ATO, OPM ve EVA kullanıımıştır. Ayrıca, bu çalışmada, bağımsız değişken olarak finansal kriz, cari oran, nakit oranı, likidite oranı, ve nakit dönüşüm döngüsü ve bu çalışmanın amacına yönelik olarak yapılan Regresyon, ANOVA ve Durbin-Watson analizlerindeki kontrol değişkeni olarak da BiST 100 işletmelerinin büyüklüğünü belirleyen toplam varlıkları (Size) ve Leverage kullanılmıştır.

Finansal krizin muhasebe ve değer esaslı işletme performans ölçülerine etkisini araştırmak için çoklu doğrusal regresyon modeli kullanılmıştır. Bağımlı değişkendeki değişmelerin birden fazla bağımsız değişken tarafindan açıklandığı regresyon modelleri çoklu regresyon modeli denir. Çoklu regresyon modelinde kullanılan bağımsız değişkenler arasındaki yüksek korelasyonlardan kaynaklanan problem için kullanılan istatistiksel terim, çoklu doğrusallık veya sadece eşdoğrusallıktır. Eşdoğrusallık kavramı ise, bir veya daha fazla bağımsız değişkenin diğer bağımsız değişkenlerin doğrusal bir birleşimi olduğu anlamına gelmektedir (Fabozzi et al., 2014; 81-82). Çalışmada, çoklu regresyon modelinde birden fazla bağımsız değişkenin yer alması söz konusu modelin kullanılmasına gerekçe teşkil etmektedir. Bu bağlamda, finansal krizin, EVA, ROA, ROE, ATO ve OPM üzerindeki etkisini tespit etmek için oluşturulan modeller aşağıda verilmiştir. Araştırmada, finansal krizin işletmelerin muhasebe ve değer esaslı performans ölçülerine etkisi incelenirken 5 modelden yararlanılmıştır.

$E V A=\mathrm{B}_{0}+\mathrm{B}_{1} \mathrm{X}_{1}+\mathrm{B}_{2} \mathrm{X}_{2}+\mathrm{B}_{3} \mathrm{X}_{3}+\mathrm{B}_{4} \mathrm{X}_{4}+\mathrm{B}_{5} \mathrm{X}_{5}+\mathrm{B}_{6} \mathrm{X}_{6}+\ldots \ldots+\mathrm{B}_{\mathrm{n}} \mathrm{X}_{\mathrm{n}} \quad$ (Model 1)

EVA $=$ Bağımlı Değişken

$\boldsymbol{X}_{\boldsymbol{n}}=$ Bağımsız Değişkenler (Modelde CCC, CURRENT, QUICK, CASH, FS ve FL)

$\boldsymbol{R O A}=\mathrm{B}_{0}+\mathrm{B}_{1} \mathrm{X}_{1}+\mathrm{B}_{2} \mathrm{X}_{2}+\mathrm{B}_{3} \mathrm{X}_{3}+\mathrm{B}_{4} \mathrm{X}_{4}+\mathrm{B}_{5} \mathrm{X}_{5}+\mathrm{B}_{6} \mathrm{X}_{6}+\ldots \ldots+\mathrm{B}_{\mathrm{n}} \mathrm{X}_{\mathrm{n}} \quad$ (Model 2)

$\boldsymbol{R O A}=$ Bağımlı Değişken

$\boldsymbol{X}_{n}=$ Bağımsız Değişkenler (Modelde CCC, CURRENT, QUICK, CASH, FS ve FL)

$R O E=\mathrm{B}_{0}+\mathrm{B}_{1} \mathrm{X}_{1}+\mathrm{B}_{2} \mathrm{X}_{2}+\mathrm{B}_{3} \mathrm{X}_{3}+\mathrm{B}_{4} \mathrm{X}_{4}+\mathrm{B}_{5} \mathrm{X}_{5}+\mathrm{B}_{6} \mathrm{X}_{6}+\ldots \ldots . .+\mathrm{B}_{\mathrm{n}} \mathrm{X}_{\mathrm{n}} \quad$ (Model 3)

$\boldsymbol{R O E}=$ Bağımlı Değişken

$\boldsymbol{X}_{\boldsymbol{n}}=$ Bağımsız Değişkenler (Modelde CCC, CURRENT, QUICK, CASH, FS ve FL)

$\boldsymbol{A T O}=\mathrm{B}_{0}+\mathrm{B}_{1} \mathrm{X}_{1}+\mathrm{B}_{2} \mathrm{X}_{2}+\mathrm{B}_{3} \mathrm{X}_{3}+\mathrm{B}_{4} \mathrm{X}_{4}+\mathrm{B}_{5} \mathrm{X}_{5}+\mathrm{B}_{6} \mathrm{X}_{6}+\ldots \ldots . .+\mathrm{B}_{\mathrm{n}} \mathrm{X}_{\mathrm{n}} \quad$ (Model 4)

$\boldsymbol{A T O}=$ Bağımlı Değişken

$\boldsymbol{X}_{\boldsymbol{n}}=$ Bağımsız Değişkenler (Modelde CCC, CURRENT, QUICK, CASH, FS ve FL)

OPM $=\mathrm{B}_{0}+\mathrm{B}_{1} \mathrm{X}_{1}+\mathrm{B}_{2} \mathrm{X}_{2}+\mathrm{B}_{3} \mathrm{X}_{3}+\mathrm{B}_{4} \mathrm{X}_{4}+\mathrm{B}_{5} \mathrm{X}_{5}+\mathrm{B}_{6} \mathrm{X}_{6}+\ldots \ldots+\mathrm{B}_{\mathrm{n}} \mathrm{X}_{\mathrm{n}} \quad$ (Model 5)

OPM = Bağımlı Değişken

$\boldsymbol{X}_{\boldsymbol{n}}=$ Bağımsız Değişkenler (Modelde CCC, CURRENT, QUICK, CASH, FS ve FL)

Bağımsız değişkenler arasında karşılıklı ilişki bulunması durumuna çoklu doğrusal bağınt (multicollinearity) olarak adlandırılmaktadır. Çoklu doğrusal bağlant, modelde bulunan bağımsız değişkenlerin tümünün veya bir kısmının kendi aralarında güçlü bir ilişkiye sahip olmalarını ifade etmektedir. 
Çoklu doğrusallığın tespit edilmesinde ise varyans enflasyon faktörü (Variance Inflation Factor) testi modellere uygulanmıştır. Regresyon katsayısının orijinal varyansını düzeltme terimine varyans enflasyon faktörü (VIF) denir. Genel olarak, VIF için bir kıyaslama yapılması halinde değerin 10'u aşmaması gerekir. Ayrıca, 10'u aşan bir VIF, çoklu doğrusallığa bağlı olarak önemli bir etkiyi gösterir ve bağımsız değişken, regresyondan en iyi şekilde çıkartılmış olur (Fabozzi vd., 2014; 84). Bazı yazarlar VIF'yi çoklu doğrusallığın bir göstergesi olarak kullanmaktadır. VIFj değeri ne kadar büyük olursa, değişken Xj daha eş-lineerdir. Kural olarak, eğer bir değişkenin VIF değeri 10'u aşarsa, R2j değeri 0.90'ı olur ve bu değişkenin çok lineer veya çoklu doğrusallı̆̆ın göstergesi olduğunu ifade etmektedir (Gujarati, 2003; 362).

\section{Araştırmanın Bulguları}

\subsection{Betimleyici İstatistikler}

Yatırımcıların gelirlerini artırmalarına yönelik olarak en iyi yatırım seçeneklerini araştırmaları, şirketlerin finansal performans değerlendirmesi, paydaşlar, alacaklılar ve aynı sektördeki şirketler için daha da önem kazanmaktadır. Dolayısıyla, finansal performansın değerlendirmesi, borsaya kayıtlı işletmelerin bilanço, gelir tablosu ve nakit akışından gelen verilere göre finansal oranların kullanılmasıyla ölçülebilir. Finansal oranlar ise, finansal bilgi kullanıcıları tarafindan kararlar almak için ilgili verilerin analiz edilerek faydalı bilgiler sağlamaktadır (Rezaie vd., 2014; 5033-5034). Bu bağlamda çalışmada, finansal krizin BiST 100 ' deki işletmelerin likiditesini etkileyip etkilemediği, bir başka ifadeyle işletmelerin likidite oranları ve nakit döngüsünün performans göstergelerinde etkisi olup olmadığı incelenmiştir.

Araştırmada kullanılan analizlerdeki istatistiki bilgiler Tablo 1'de gösterilmiştir.

Tablo 1. İstatistiki Bilgiler

\begin{tabular}{|l|l|}
\hline Ekonomik Katma Değer (EVA) & $\begin{array}{l}\text { Vergi Sonrası Net Faaliyet Karı (NOPAT) - Sermayenin Ağılıklı Ortalama Maliyeti } \\
\text { (WACC)* x Kullanılan Sermaye (Firmanın EVA'sının Doğal Logaritması) }\end{array}$ \\
\hline Aktif Karlılığı (ROA) & Net Kar (Zarar) / Toplam Varlıklar Toplamı \\
\hline Öz Kaynak Karlılığı (ROE) & Net Kar (Zarar) / Öz Kaynaklar Toplamı \\
\hline Aktif Devir Hızı (ATO) & Net Satışlar/Toplam Varlıklar \\
\hline Faaliyet Karı Marjı (OPM) & Faiz ve Vergi Öncesi Kar/ Net Satışlar \\
\hline $\begin{array}{l}\text { Nakit Dönüşüm Döngüsü } \\
\text { (CCC) }\end{array}$ & $\begin{array}{l}\text { Alacakların Tahsil Süresi (ARP) +Stokların Devir Süresi (ICP) - Borçların Devir Süresi } \\
\text { (APP) }\end{array}$ \\
\hline Cari Oran (CR) & Dönen Varlıklar / Kısa Vadeli Yabancı Kaynaklar \\
\hline Likidite Oranı (QR) & Dönen Varlıklar- Stoklar / Kısa Vadeli Yabancı Kaynaklar \\
\hline Nakit Oranı (NR) & Nakit Varlıklar/ Kısa Vadeli Yabancı Kaynaklar \\
\hline Firma Büyüklüğü (FS) & Firma Toplam Varlıklarının Doğal Logaritması \\
\hline Finansal Kaldıraç (FL) & Toplam Borçlar / Toplam Varlıklar \\
\hline
\end{tabular}

Kaynak: Yazarların kendisi tarafindan oluşturulmuştur.

*Sermayenin ağırlıklı ortalama maliyeti (WACC) oranı olarak, sermaye maliyetinin her bir firma için ayrı ayrı hesaplanmasının oldukça zor olmasından ötürü Merkez Bankası Mevduat Faiz Oranlarının Ağırlıklı Ortalaması dikkate alınmıştır.

Söz konusu istatistiki bilgiler ışığında, betimleyici istatistikler ise Tablo 2'de gösterilmiştir. 
Tablo 2. Betimleyici İstatistikler (Descriptive Statistics)

\begin{tabular}{|l|c|c|c|c|c|c|}
\hline & \multicolumn{3}{|c|}{ Finansal Kriz Sonrası } & \multicolumn{3}{c|}{ Finansal Kriz Öncesi } \\
\hline Değişkenler & Mean & Std. Deviation & $\mathbf{N}$ & Mean & $\begin{array}{l}\text { Std. } \\
\text { Deviation }\end{array}$ & $\mathbf{N}$ \\
\hline EVA & 0 & 0,728306 & 500 & 7,27208 & 0,685505 & 500 \\
\hline ROA & 0,0043 & 0,125339 & 500 & 0,01714 & 0,175129 & 500 \\
\hline ROE & $-0,19766$ & 1,707465 & 500 & $-0,10106$ & 1,341343 & 500 \\
\hline ATO & 1,76788 & 0,309177 & 500 & 1,62116 & 0,306405 & 500 \\
\hline OPM & 0,0506 & 0,120811 & 500 & 0,03728 & 0,174738 & 500 \\
\hline CCC & 1,9228 & 0,482718 & 500 & 1,93128 & 0,490311 & 500 \\
\hline CURRENT & 1,56212 & 0,793706 & 500 & 1,6826 & 0,817911 & 500 \\
\hline QUICK & 1,05436 & 0,622088 & 500 & 1,11174 & 0,690636 & 500 \\
\hline CASH & 0,2347 & 0,32331 & 500 & 0,22454 & 0,325261 & 500 \\
\hline FS & 8,40718 & 0,702928 & 500 & 8,23386 & 0,653527 & 500 \\
\hline FL & 0,62296 & 0,717685 & 500 & 0,53584 & 0,450216 & 500 \\
\hline
\end{tabular}

Tablo 2'ye göre, finansal kriz sonrası dönemlerde kriz öncesi döneme kıyasla muhasebe esaslı performans ölçülerinden ROA ve ROE azalırken ATO ve OPM'de artş olmuştur. Ayrıca, değer esası ı performans ölçüsü olan EVA ise finansal kriz sonrası dönemlerde kriz öncesi döneme kıyasla azalmıştr. Dolayısıyla, finansal kriz sonrası dönemlerinde BiST 100'de hisseleri işlem gören işletmelerin ATO ve OPM hariç işletme performans ölçülerinde olumsuz oranda etkilenmiştir. Tablo 2'ye göre, finansal kriz sonrası dönemlerde kriz öncesi döneme kıyasla işletmelerin nakit dönüşüm döngüsü, cari oran ve likidite oranı azalırken, nakit oranlarında bir artış olmuştur. Ayrıca, işletmelerin finansal kaldıraç oranlarındaki artşla birlikte, toplam varlıkların bir artı̧̧ olduğu gözlemlenmiştir.

Finansal kriz sonrasındaki dönemlerde, BIST 100'de işlem gören şirketlerin ROE ve ROA'larının azalması, işletme yönetiminin sermaye fonlarını etkili kullanamadığını ve şirketin kaynaklarını ise verimsiz bir biçimde kullandıklarını gösterebilir.

\subsection{Analiz Sonuçları}

Bu bölümde, araşttrmada ele alınan modellere göre, finansal kriz öncesi ve sonrası BiST 100'de işlem gören şirketlerin performanslarındaki değişim incelenecektir.

Tablo 3'de gösterilen F testi analizlerine göre, finansal kriz sonrası dönemlerde kriz öncesi döneme kıyasla hem muhasebe esaslı performans ölçülerinde (OPM hariç) ve hem de değer esaslı performans ölçüsü olan EVA'nın R değerlerinde artış olduğu gözlemlenmiştir. Ayrıca, $\mathrm{F}$ testine ait \%5 anlamlılık düzeyinde finansal kriz sonrası dönemlerde kriz öncesi döneme kıyasla daha bağımlı değişkenlerin bağımsız değişkenleri açıklama ilişkisinin anlamlı olduğunu söyleyebiliriz. Dolayısıyla, finansal kriz sonrası dönemlerinde BiST 100'de hisseleri işlem gören işletmelerin işletme performans ölçülerinde olumlu düzeyde ve pozitif yönlü etkilendiği sonucuna varılabilir. Ayrıca, bağımsız değişkenlerin hem muhasebe esaslı performans ölçülerinde (OPM hariç) ve hem de değer esaslı performans ölçüsü olan EVA üzerinde anlamlı etkiye sahip oldukları görülürken (Sig. F chance 0.000), finansal kriz sonrası dönemlerde BIST 100'de hisseleri işlem gören işletmelerin performanslarını artırmalarının en önemli göstergelerinden birinin aktiflerini etkin kullandıkları söylenebilir.

Tablo 3'deki gerek finansal kriz öncesi döneme, gerekse kriz sonrası döneme ilişkin $\mathrm{F}$ değerleri ve anlamlılık düzeyleri tüm modellerin anlamlı olduğunu göstermektedir. Çalışmada, regresyonda oluşan artan değerler arasındaki oto korelasyonu tespit etmek için Durbin-Watson testi uygulanmıştr. Tüm modellerdeki Durbin-Watson analizindeki sonuçlarına göre, değerlerin $2^{\prime}$ ye yakın olduğunu yani değerlerin oto korelasyonu olmadığı anlamına geldiğini söyleyebiliriz. 
Ayrıca Tablo 3'deki verilere göre, finansal kriz öncesi dönemde EVA'nın yüzde 9,6'sı, ROA'nın 8,9'u, ROE'nin 3,4'ü, ATO'nun 9,1'i ve OPM'nin 8'i bağımsız değişkenler tarafindan açıklanabilirken, finansal kriz sonrası dönemde ise EVA'nın yüzde 46,8'i, ROA'nın 36'sı, ROE'nin 27,1'i, ATO'nın 25,6'sı ve OPM'nin 5,8'i bağımsız değişkenler tarafindan açıklanabilmektedir. Tablodaki regresyon analizi sonuçlarına göre $\mathrm{H} 1, \mathrm{H} 2$, $\mathrm{H} 3$ ve $\mathrm{H} 4$ hipotezleri kabul edilirken, $\mathrm{H} 5$ hipotezi reddedilmiştir. Ayrıca, modele ilişkin analiz incelendiğinde EVA performans göstergesine her bir bağımsız değişkenin de anlamlı katkı sağladığı bulunmuştur. Muhasebe esaslı performans göstergeleri açısından konuyu değerlendirecek olursak, finansal kriz sonrasında BiST 100' de işlem gören işletmelerin en yüksek performans ölçütüne ROA değişkenin sahip olduğu görülmektedir.

Tablo 3. Araştırma Modellerine Göre İşletmelerin Performans Değişimi

\begin{tabular}{|c|c|c|c|c|c|c|c|c|c|c|}
\hline \multicolumn{11}{|c|}{ Finansal Kriz Sonrası } \\
\hline \multirow[b]{2}{*}{ Model } & \multirow[b]{2}{*}{$\mathrm{R}$} & \multirow[b]{2}{*}{$\begin{array}{c}\mathrm{R} \\
\text { Square }\end{array}$} & \multirow[b]{2}{*}{$\begin{array}{l}\text { Adjusted } \\
\text { R Square }\end{array}$} & \multirow{2}{*}{$\begin{array}{l}\text { Std. } \\
\text { Error of } \\
\text { the } \\
\text { Estimate }\end{array}$} & \multicolumn{5}{|c|}{ Change Statistics } & \multirow[b]{2}{*}{$\begin{array}{l}\text { Durbin- } \\
\text { Watson }\end{array}$} \\
\hline & & & & & $\begin{array}{c}\text { R } \\
\text { Square } \\
\text { Change }\end{array}$ & $\begin{array}{c}\mathrm{F} \\
\text { Change }\end{array}$ & df1 & $\mathrm{df} 2$ & $\begin{array}{l}\text { Sig. F } \\
\text { Change }\end{array}$ & \\
\hline EVA & 0,684 & 0,468 & 0,462 & 0,534428 & 0,468 & 72,287 & 6 & 493 & 0,000 & 1,914 \\
\hline ROA & 0,600 & 0,360 & 0,352 & 0,100867 & 0,360 & 46,251 & 6 & 493 & 0,000 & 1,940 \\
\hline ROE & 0,271 & 0,074 & 0,062 & 1,653396 & 0,074 & 6,528 & 6 & 493 & 0,000 & 1,936 \\
\hline ATO & 0,506 & 0,256 & 0,247 & 0,268316 & 0,256 & 28,259 & 6 & 493 & 0,000 & 1,929 \\
\hline OPM & 0,240 & 0,058 & 0,046 & 0,117989 & 0,058 & 5,026 & 6 & 493 & 0,000 & 2,025 \\
\hline \multicolumn{11}{|c|}{ Finansal Kriz Öncesi } \\
\hline \multirow[b]{2}{*}{ Model } & \multirow[b]{2}{*}{$\mathrm{R}$} & \multirow[b]{2}{*}{$\begin{array}{c}\mathrm{R} \\
\text { Square }\end{array}$} & \multirow[b]{2}{*}{$\begin{array}{l}\text { Adjusted } \\
\text { R Square }\end{array}$} & \multirow{2}{*}{$\begin{array}{l}\text { Std. } \\
\text { Error of } \\
\text { the } \\
\text { Estimate }\end{array}$} & \multicolumn{5}{|c|}{ Change Statistics } & \multirow[b]{2}{*}{$\begin{array}{l}\text { Durbin- } \\
\text { Watson }\end{array}$} \\
\hline & & & & & $\begin{array}{c}\mathrm{R} \\
\text { Square } \\
\text { Change }\end{array}$ & $\begin{array}{c}\mathrm{F} \\
\text { Change }\end{array}$ & df1 & $\mathrm{df2}$ & $\begin{array}{l}\text { Sig. F } \\
\text { Change }\end{array}$ & \\
\hline EVA & 0,310 & 0,096 & 0,085 & 0,655577 & 0,096 & 8,767 & 6 & 493 & 0,000 & 1,609 \\
\hline ROA & 0,298 & 0,089 & 0,078 & 0,168206 & 0,089 & 7,987 & 6 & 493 & 0,000 & 1,898 \\
\hline ROE & 0,185 & 0,034 & 0,022 & 1,326252 & 0,034 & 2,903 & 6 & 493 & 0,009 & 2,025 \\
\hline ATO & 0,301 & 0,091 & 0,08 & 0,293938 & 0,091 & 8,204 & 6 & 493 & 0,000 & 1,873 \\
\hline OPM & 0,282 & 0,080 & 0,069 & 0,168643 & 0,080 & 7,120 & 6 & 493 & 0,000 & 1,860 \\
\hline
\end{tabular}

Tablo 4'deki analiz sonuçlarına göre, $T$ istatistik değerleri ve anlamlılık düzeylerine göre finansal kriz öncesi dönemde bağımlı değişken EVA ile bağımsız değişken NR ve kontrol değişkeni FS arasında anlamlı ve pozitif ilişki bulunurken, finansal kriz sonrası dönemde bağımlı değişken EVA değerleri ile NR ve kontrol değişkenleri FS ve FL arasında anlamlı ve pozitif bir ilişki saptanmıştır. Ayrıca, gerek kriz öncesi dönemde, gerekse kriz sonrası dönemde VIF değerlerine göre bağımsız değişkenler arasında çoklu bağlantı sorunu bulunmamaktadır.

EVA'yı bağımsız değişkenlerin açıklama gücü ise, finansal kriz sonrası dönemlerde nakit oranı, firma büyüklüğü ve finansal kaldıraç derecesinde anlamlılık gösterirken, finansal kriz öncesi dönemlerinde nakit oranı ve firma büyüklüğü ile anlamlılık göstermektedir. Ayrıca, BiST 100'de işlem gören işletmelerin finansal kriz dönemi sonrası dönemlerde finansal kriz dönemi öncesine kıyasla finansal borçlanma katsayısının arttğı gözlemlenmiştir. Bu durum, Tortella ve Brusco (2003) çalışmasındaki sonuçlarla uyumlu olduğu gözlemlenmiştir. Tortella ve Brusco (2003) EVA'nın benimsenmesinin şirketin yatırım faaliyetini artırdığını ve finansal borç oranındaki artşları da beraberinde götürdüğünü gözlemlemiştir.

Tablo 5'deki verilere göre finansal kriz öncesi dönemde bağımlı değişken ROA ile bağımsız değişken CCC (Nakit dönüşüm hızı) arasında anlamlı ve negatif yönde bir ilişki bulunurken, bağımsız değişken CR (Cari oran) arasında anlamlı ve pozitif bir ilişki bulunmuştur. Diğer yandan finansal kriz sonrası dönemde ROA ile 
bağımsız değişken CR ile kontrol değişkeni FS (Firma büyüklüğü) arasında anlamlı ve pozitif bir ilişki bulunurken, diğer kontrol değişkeni FL (Kaldıraç oranı) arasında anlamlı ve negatif bir ilişki saptanmıştır.

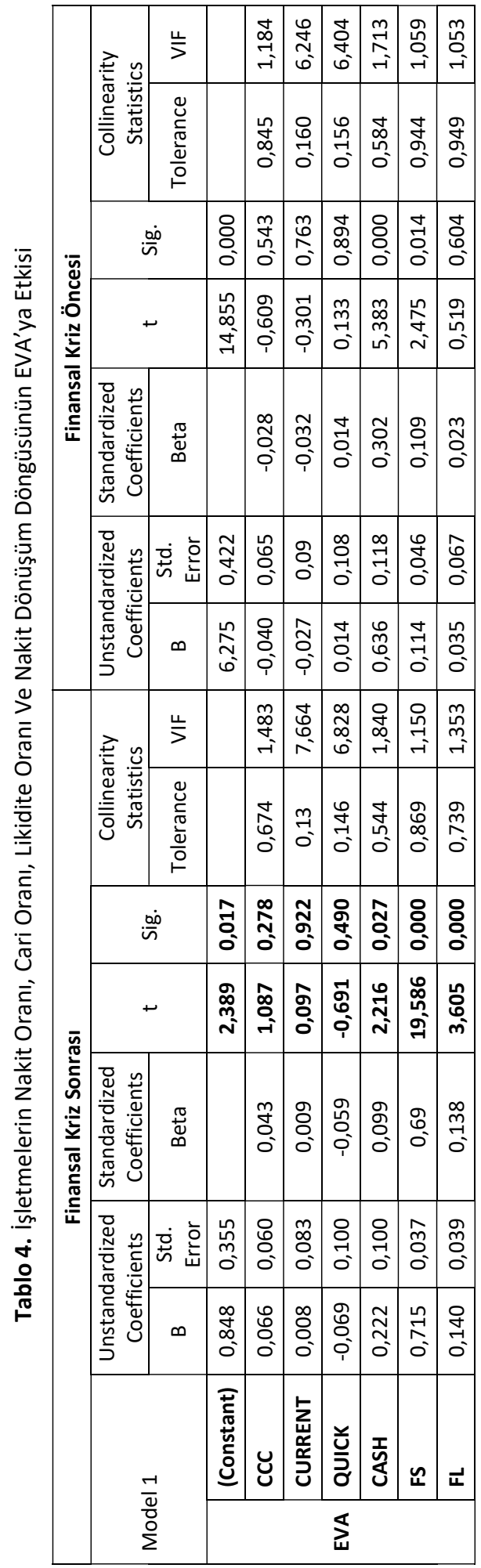

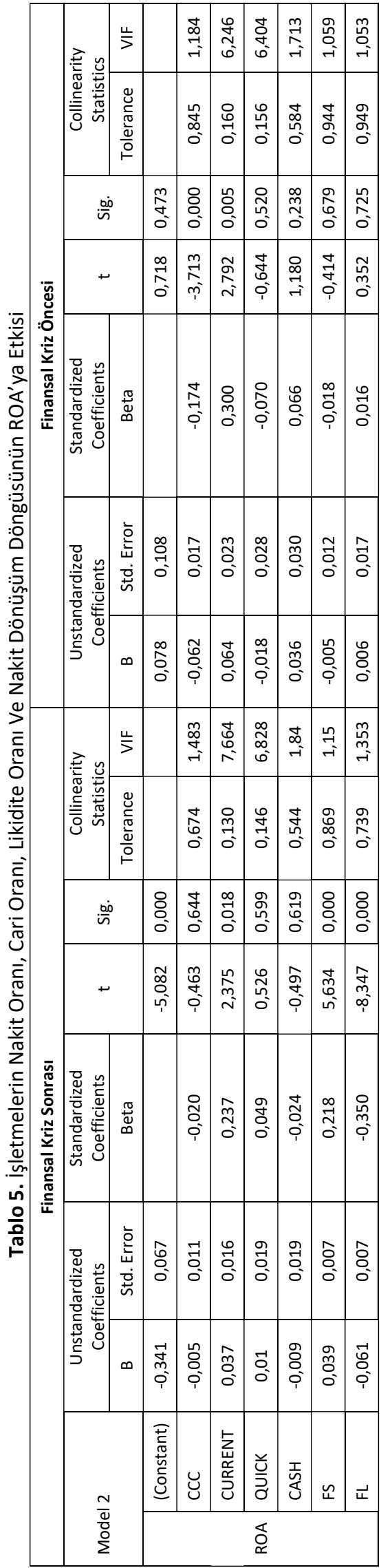




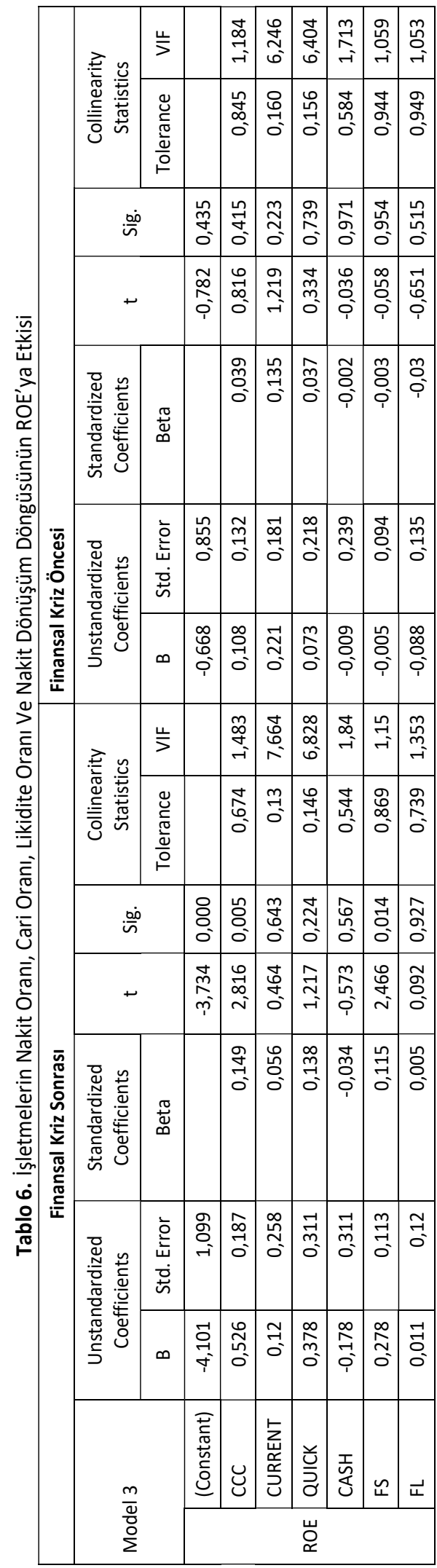

Tablo 6 verilerine göre finansal kriz öncesi dönemde bağımlı değişken ROE ile bağımsız değişkenler ve kontrol değişkenleri arasında anlamlı bir ilişki bulunamamıştır. Finansal kriz sonrası dönemde ise yalnızca kontrol değişkeni FS ile ROE arasında anlamlı ve pozitif yönde bir ilişki bulunmuştur. Ayrıca, Tablo 6'daki verilere göre, Öz kaynak Kârııı̆̆ı (ROE) için finansal kriz sonrası dönemlerde anlamlılık seviyesi $\alpha$ değerinden $(0.05)<0,000$ daha düşük bir önem seviyesine sahiptir. 

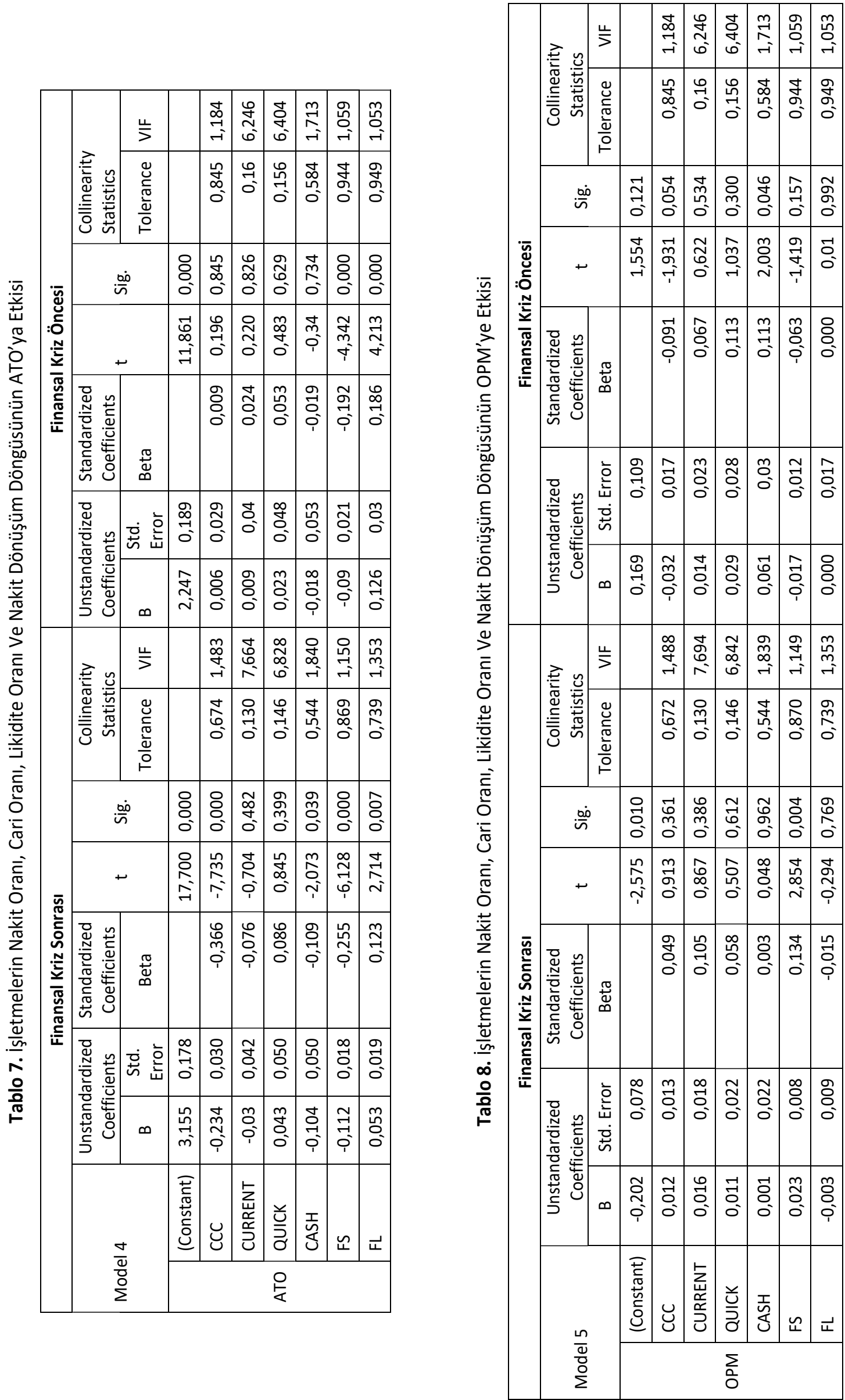
Tablo 7'deki analiz sonuçlarına göre finansal kriz öncesi dönemde bağımlı değişken ATO (Aktif devir hızı) bağımsız değişkenler CCC, CR, QR, NR arasında anlamlı bir ilişki bulunamazken, kontrol değişkeni FS arasında anlamlı ve negatif bir ilişki, diğer kontrol değişkeni $\mathrm{FL}$ arasında anlamlı ve pozitif bir ilişki saptanmıştır. Finansal kriz sonrası dönemde ise bağımlı değişken ATO ile bağımsız değişkenler CCC, NA ve kontrol değişkeni FS arasında anlamlı ve negatif bir ilişki saptanmıştır. Ayrıca, Tablo 7'deki verilere göre, finansal kriz sonrası dönemlerde finansal kriz öncesi dönemine kıyasla, BIST 100'deki şirketlerin cari oran ile aktif devir hızı oranı arasında olumsuz etkilerin varlığı, dönen varlıklarda gösterilen ve satışa hazır stokların yetersiz olduğunu gösterebilir.

Tablo 8'deki regresyon analizi sonuçlarına göre finansal kriz öncesi dönemde bağımlı değişken OPM (Faaliyet kar marjı) ile CCC arasında anlamlı ve negatif bir ilişki bulunurken diğer değişkenler ile anlamlı bir ilişki bulunamamıştır. Finansal kriz sonrası dönemde ise OPM ile bağımsız ve kontrol değişkenleri arasında anlamlı bir ilişki bulunamamıştır. Dolayısıyla, Faaliyet Kâr Marjı (OPM), finansal kriz sonrası dönemde $\alpha$ değerinden $(0.05)<0,010$ daha düşük bir önem seviyesine sahiptir. OPM'nın anlamlılık düzeyi $<\alpha=0.05$ ise, BIST 100' de işlem gören şirketlerin faaliyet kar marjı negatif ve anlamlı bir etkiye sahip olduğunu gösteriyor. Aksine, finansal kriz öncesi dönemde ise, BiST 100'de işlem gören şirketlerin faaliyet kâr marjının satış büyümesi üzerinde \%12 anlamlılık düzeyinde pozitif ve anlamlı etkisi olduğunu göstermektedir. Bunun nedeni, şirketlerin OPM oranının yüksek olması, yüksek satışlardan da kaynaklanan yüksek kazanç artışına sahip olma eğiliminden kaynaklanmasıdır.

\section{Sonuç}

İşletme performansının ölçülmesinde kullanılan öz kaynak kârıılığı, aktif karlılığı, faaliyet kar marjı ve aktif devir hızının yanı sıra ekonomik katma değer (EVA), yöneticilerin teşviklerini hissedarların teşviklerine daha iyi uyumu sağlamak için geliştirilmiş bir performans ölçüsüdür. EVA, performans ölçümünde karın sermaye maliyetine göre düzeltilmesini dikkate alarak, firmaların performans değerlendirme sisteminde önemli role sahiptir. Ayrıca, EVA finansal yönetim sisteminde, bir şirketin hissedar değeri yaratması için gereken her projede sermaye maliyetinden daha fazla kazanması gerektiğini ifade etmektedir.

Bu çalışmada yapılan analizlere göre, finansal kriz dönemlerinde kriz öncesine göre işletme performans ölçüsü olan EVA'nın BIST 100 işletmelerinde olumlu yönde değiştiğini ortaya koymaktadır. Ayrıca, BIST 100'de işlem gören işletmelerin finansal kriz sonrası dönemlerinde muhasebe esaslı işletme performans ölçülerinden ROA, gelir artş̧ıla birlikte varlık getirisi arasında belirgin ve olumlu bir sonuç doğurmuştur. Bu çalışmanın sonuçlarına göre BIST 100'deki işletmelerin ROA göstergeleri, şirketlerin kâr elde etmek için finansal kriz öncesi döneme göre ne kadar etkili çalıştğını göstermektedir. Ayrıca, finansal kriz sonrası dönemlerinde ROE performans ölçüsüne göre, BIST 100'deki şirketlerin 2008-2012 dönemlerinde şirketlerin kazançlarında olumlu ve belirgin bir etkisi olduğunu göstermektedir. Söz konusu analiz sonuçları ise, literatürdeki araştırmalardan Ongore ve Kusa (2013) ile Worthinggton ve West (2004) çalışmalarıyla uyumlu olduğunu ortaya koymuştur.

BIST 100'de faaliyet gösteren işletmelerin finansal kriz öncesi dönemi ile finansal kriz sonrası dönem arasında modern performans ölçüm yöntemi olarak kabul edilen EVA değerleri ile geleneksel ölçüm yöntemleri olarak kabul edilen ROA, ROE, ATO ve OPM ölçüm yöntemleri ile bağımsız değişkenler CCC, CR, $\mathrm{QR}$, NA ve kontrol değişkenleri FS ile FL arasındaki karşılaştırma sonuçlarına göre finansal kriz sonrası dönemde bağımsız değişkenlerin bağımlı değişkenleri açıklama oranı daha yüksek bulunmuştur. Ayrıca, finansal kriz sonrası dönemde bağımsız değişkenlerin bağımlı değişken ve değer esaslı performans ölçüm yöntemi olan EVA'yı açıklama gücü daha yüksek bulunmuştur.

Araştırma sonuçlarına göre, finansal kriz sonrası dönemlerde BIST 100'de işlem gören şirketlerin varlıklarındaki aktif karlıı̆̆̆, öz kaynak kârııı̆ı, faaliyet kar marjı, finansal kriz öncesi döneme göre finansal kriz sonrası dönemlerde olumlu ve belirgin etkisi bulunmaktadır. Gelecekteki araştırma, finansal krizinin egemen olduğu dönemde BiST'deki tüm işletmelerin finansal performans göstergelerinin nakit akış dalgalanmalarına etkisi bulunan faktörleri inceleyebiliriz. 


\section{Kaynaklar}

Akhigbe, A., McNulty, James E., \& Bradley A. S. (2017). Does the form of ownership affect firm performance? Evidence from US bank profit efficiency before and during the financial crisis. The Quarterly Review of Economics and Finance, 64, 120-129.

Baek, Jae-Seung, Kang, Jun-Koo, \& Park, K.S. (2004). Corporate governance and firm value: Evidence from the Korean financial crisis. Journal of Financial Economics, 71, 265-313.

Berzakova, V., Bartosova, V., \& Kicova, E. (2015). Modification of EVA in value based management. 4th World Conference on Business, Economics and Management, WCBEM, Procedia Economics and Finance 26, 317-324.

Bhimjee, D.C., Ramos, S.B., \& Dias, J.G. (2016), Banking industry performance in the wake of the global financial crisis. International Review of Financial Analysis, 48, 376-387.

Bouslah, K., Kryzanowski, L., \& M'Zali, B. (2016). Social performance and firm risk: Impact of the financial crisis. Journal of Business Ethics, 1-27.

Chen, Q., Filardo, A., He, D., \& Zhu, F. (2016). Financial crisis, US unconventional monetary policy and international spillovers. Journal of International Money and Finance, 67, 62-81.

Chen, S., \& Dodd, J.L. (1997). Economic Value Added (EVA): An empirical examination of a new corporate performance measure. Journal of Managerial Issues, 9(3), 318-333.

Cornett, M.M., Erhemjamts, O., \& Tehranian, H. (2016). Greed or good deeds: An examination of the relation between corporate social responsibility and the financial performance of U.S. commercial banks around the financial crisis. Journal of Banking and Finance, 70, 137-159.

Ducassy, I. (2013). Does corporate social responsibility pay off in times of crisis? An alternate perspective on the relationship between financial and corporate social performance. Corporate Social Responsibility and Environmental Management, 20, 157-167.

Fabozzi, F.J., Focardi, S.M., Rachev, S.T., Arshanapalli, B.G., \& Hoechstoetter, M. (2014). The basics of financial econometrics: Tools, concepts, and asset management. New Jersey: John Wiley \& Sons, Inc.

Fratzscher, M., König, F.J., \& Lambert, C. (2016). Credit provision and banking stability after the Great Financial Crisis: The role of bank regulation and the quality of governance. Journal of International Money and Finance, 66, 113135.

Gujarati, D.N. (2003). Basic econometrics. Fourth Edition, New York: McGraw-Hill Companies, Inc.

Hawawini, G., Subramanian, V., \&Verdin, P. (2003). Is performance driven by industry-or firm-specific factors? A new look at the evidence. Strategic Management Journal, 24(1), 1-16.

Hoa, Po-Hsin, Huangb, Chia-Wei, Linc, C.Y., \& Yen, J-F. (2016). CEO overconfidence and financial crisis: Evidence from bank lending and leverage. Journal of Financial Economics, 120, 194-209.

Huang, C., \& Wang, M-C. (2008). The effects of economic value added and intellectual capital on the market value of firms: An empirical study. International Journal of Management, 25(4), 722-731.

Ismail, A. (2006). Is economic value added more associated with stock return than accounting earnings? The UK evidence. International Journal of Managerial Finance, 2(4), 343-353.

Jacobson, R. (1987). The validity of ROI as a measure of business performance. The American Economic Review, 77(3), 470-478.

Kestens, K., Cauwenberge, P.V., \& Bauwhede, H.V. (2012). Trade credit and company performance during the 2008 financial crisis. Accounting and Finance, 52, 1125-1151.

Kwan, S. (2004). Risk and return of publicly held vs. privately owned banks. In Beyond Pillar 3 in international banking regulation: Disclosure and market discipline of financial firms, In Conference proceedings, economic policy review (pp. 97-107). Federal Reserve Bank of New York, 10.

Kyriazis, D., \& Anastassis, C. (2007). The validity of the economic value added approach: An empirical application. European Financial Management, 13(1), 71-100.

Lehn, K., \& A. K. Makhija. (1996). EVA \& MV A as performance measures and signals for strategic change. Strategy and Leadership, 24, 34-38.

Lev, B., \& Zarowin, P. (1999). The boundaries of financial reporting and how to extend them. Journal of Accounting research, 37, 353-386.

Lovata, L.M., \& Costigan, M.L. (2002). Empirical analysis of adopters of economic value added. Management Accounting Research, 13, 215-228. 
Machuga, S.M., Pfeiffer, R.J., \& Verma, K. (2002). Economic value added, future accounting earnings, and financial analysts' earnings per share forecasts. Review of Quantitative Finance and Accounting, 18, 59-73.

Mackey, A., Mackey, T.B., \& Barney, J.B. (2007). Corporate social responsibility and firm performance: Investor preferences and corporate strategies. Academy of Management Review, 32(3), 817-835.

Margolis, J. D., \& Walsh, J. P. (2001). People and profits? The search for a link between a company's social and financial performance. New York: Psycholog Press Taylor and Franchis Group.

Mitton, T. (2002). A cross-firm analysis of the impact of corporate governance on the East Asian financial crisis. Journal of Financial Economics, 64, 215-241.

Mondal, A., \& Ghosh, Kumar, S. (2012). Intellectual capital and financial performance of Indian banks. Journal of Intellectual Capital, 13(4), 515-530.

Mouritsen, J. (1998). Driving growth: Economic value added versus intellectual capital. Management Accounting Research, 9, 461-482.

Ongore, V.O., \& Kusa, G.B. (2013). Determinants of financial performance of commercial banks in Kenya. International Journal of Economics and Financial Issues, 3(1), 237-252.

Orlitzky M., Schmidt, F. L., \& Rynes, S. (2003). Corporate social and financial performance: A meta-analysis. Organization Studies, 24, 403-411.

Peni, E., \& Vahamaa, S. (2012). Did good corporate governance improve bank performance during the financial crisis?. Journal of Financial Services Research, 41, 19-35.

Pulic, A. (2000). VAIC TM -an accounting tool for IC management. International Journal of Technology Management, 20(58), 702-714.

Rezaie, K., Ramiyani, S.S., Nazari-Shirkouhi, S., \& Badizadeh, A. (2014). Evaluating performance of Iranian cement firms using an integrated fuzzy AHP-VIKOR method. Applied Mathematical Modelling, 38, 5033-5046.

Rogerson, William P. (1997). Intertemporal cost allocation and managerial investment incentives: A theory explaining the use of economic value added as a performance measure. Journal of Political Economy, 105(4), 770-795.

Roztocki, N., \& Needy, K.L. (1999). Integrating activity-based costing and economic value added in manufacturing. Engineering Management Journal, 11(2), 17-22.

Şamiloğlu, F. (2004a). Faaliyet kârı, artık gelir ve ekonomik katma değer: Hangisi hisse senedi getirileri ile daha yüksek ilişkilidir?. İstanbul Üniversitesi Iş̧letme Fakültesi Dergisi, 33(1), 7-20.

Şamiloğlu, F. (2004b). Performans ölçümünde eva ve mva: İstanbul Menkul Kıymetler Borsası'ndaki şirketlerde ampirik bir uygulama. H.Ü. Iktisadi ve Idari Bilimler Fakültesi Dergisi, 22(2), 163-174.

Shad, M.K., \& Lai, F.W. (2015). A Conceptual framework for enterprise risk management performance measure through economic value added. Global Business and Management Research: An International Journal, 7(2), 1-11.

Shil, N.C. (2009). Performance measures: An application of economic value added. International Journal of Business and Management, 4(3), 169-177.

Sloof, R., \& van Praag, M. (2014). Testing for distortions in performance measures: An application to residual income based measures like economic value added. Tinbergen Institute Discussion Paper, No. 14-056/V.

Stewart, G. B., III. (1991). The quest for value: The EVA management guide. Harper Business, New York.

Stewart, G.B. (1994). EVA: Fact and fantasy. Journal of Applied Corporate Finance, 7(2), 71-84.

Tortella, B. D., \& Brusco, S. (2003). The Economic Value Added (EVA): An analysis of market reaction. Advances in Accounting, 20, 265-290.

Ünlü, U., \& Saygın, O. (2014). Arındırılmış Ekonomik Katma Değer (REVA) yöntemiyle performans ölçümü: Turizm sektörü uygulaması. Muhasebe ve Finansman Dergisi, Temmuz 2014; 139-150.

Venanzi, D. (2012). Financial performance measures and value creation: The state of the art. London: Springer-Verlag Mailand.

Vieito, J.P., Wong, W.K., \& Zhu, Z.Z. (2016). Could the global financial crisis improve the performance of the G7 stocks markets?. Applied Economics, 48(12), 1066-1080.

Wallace, J., (1997). Adopting residual income-based compensation plans: Do you get what you pay for?. Journal of Accounting and Economics, 24, 275-300.

Worthington, A., \& West, T. (2004). Australian evidence concerning the information content of economic value-added. Australian Journal of Management, 29(2), 201-224. 
A. I. Akgun - F. Samiloglu

Xine, Zhao, Ting, W., \& Yuan, Z. (2012). Economic value added for performance evaluation: A financial engineering. Systems Engineering Procedia, 5, 379-387. 
This Page Intentionally Left Blank 